\title{
15
}

\section{Towards an Extractivist Bioeconomy? The Risk of Deepening Agrarian Extractivism When Promoting Bioeconomy in Argentina}

\author{
Anne Tittor
}

\subsection{Introduction: Argentina as a Bioeconomy Pioneer}

Argentina considers itself a Latin American pioneer when it comes to the bioeconomy. The debate on bioeconomy in Argentina is broader and more intense than in other countries, especially among others in the Global South. Since 2013, two national and ten regional conferences ${ }^{1}$ on bioeconomy have been held in the country, at which government representatives, researchers, actors from business and agrarian organizations

\footnotetext{
${ }^{1}$ The national conferences took place between 21 and 22 March 2013 and 5 and 6 June 2014 in Buenos Aires. The Regional Conferences in 2015 were held between 16 and 17 April in Puerto Madryn, 6 and 7 May in Posadas, 25 and 26 June in Rosario and 1 and 2 July in Tucuman. In 2016, regional symposia were held between 22 and 23 September in Cuyo, 4 and 5 October in Córdoba, 20 and 21 October in Resistencia, 17 and 19 November in Neuquén, 24 and 25 November in Salta and 11 and 13 December in Buenos Aires.
}

A. Tittor $(\bowtie)$

Friedrich-Schiller-Universität Jena, Jena, Germany

e-mail: anne.tittor@uni-jena.de 
discussed how to establish a bioeconomy that would reflect Argentina's needs and interests. A total of between 4000 and 5000 people attended these conferences (key bioeconomy policy maker, Interview no. 1).

Bioeconomy simultaneously promises sustainability, innovation and competitiveness, and promotes bioprocesses, bioproducts and biofuels. This implies increasing demand for biomass and, therefore, a huge impact on the sector producing it: primarily the agricultural sector. ${ }^{2}$ Nevertheless, Argentina's agricultural policies have been contested for several years, and the expansion of soybean monocultures in the last three decades and the related use of pesticides in particular (Teubal and Giarracca 2013a).

Against this background, this chapter asks which kind of agriculture is promoted within the bioeconomy debate in Argentina. More precisely, it examines the motivation and objectives presented by Argentinian advocates of the bioeconomy and the issues that are marginalised and excluded from the debate. It also looks at the role played by the actors that currently promote bioeconomy in Argentina within the transformation of agriculture that has taken place over the last few decades.

If bioeconomy involves agriculture delivering more than just food and fodder (it's role in the past), and instead includes the provision of additional raw materials for bioenergy such as biogas, biomaterials and bioplastics (where in most, if not all, cases, oil-based resources were used), the demand for biomass rises considerably (see also Lühmann in this volume). Therefore, a critical approach to bioeconomy should ask who aims to produce this additional biomass, under which conditions and at which social and environmental cost. Is there a danger that countries in the Global South will (once again) be pushed purely into the role of producers of resources that are intended for export, while destroying and exhausting local livelihoods and nature? This core question has been at the focus of recent debates about extractivism.

\footnotetext{
${ }^{2}$ Besides the agricultural sector, there are efforts to produce biomass using algae. These innovations, as well as other aspects of what is known as the "blue bioeconomy", are not addressed in this chapter. The same applies to the "white bioeconomy" - the medical field.
} 
Therefore, for my discussion of Argentina's bioeconomy, I refer to considerations from the Latin American centred debate about extractivism (Svampa 2012; Gudynas 2015), especially agrarian extractivism (McKay 2017), to describe the changes in Argentina's agriculture. This serves as a background to evaluate the kind of changes that the bioeconomy will bring about, and which structures will remain the same.

My analysis draws on material from several conferences and workshops on bioeconomy (listed in footnote 1), policy documents, media reports, material from web-based further education programmes and the websites of key actors. It takes into consideration the statements of the Argentinian delegation at the Global Bioeconomy Summit in Berlin 2018 as well as expert interviews with key actors conducted during field research in May and June 2018 in Buenos Aires and Córdoba (listed at the end). It further draws on the broad scientific debate in Argentina about the transformation of agriculture over the last few decades and the related problems, a debate, which I will briefly outline in the following section. Using this framework, Sect. 15.3 provides some information about the impacts of soybean expansion over the last few decades. Against this background, in Sect. 15.4 I discuss the extent to which the Argentinian debate about bioeconomy relates to the problematic impacts of soybean monocropping and the proposals to overcome them. In Sect. 15.5, I conclude that, despite some counter-tendencies, implementing the current understanding of bioeconomy in Argentina risks deepening agrarian extractivism.

\subsection{Agrarian Extractivism as a Tool for Analysing Argentina's Bioeconomy}

Over the last few years, the notion of extractivism has been widely discussed to characterize an economic model or accumulation strategy that relies on the extraction of raw materials, especially from mining activities in the Global South, and their export towards the Global North (Svampa and Viale 2014; Bebbington et al. 2014; Gudynas 2015). Although extractivism dates back to the colonial era, in the twentyfirst century a re-primarization of the economies in Latin America 
took place, which, in times of high prices for raw materials on the world market, became an important driver of growth and economical dynamics. In 2012, Maristella Svampa argued that extractivism is not limited to mining, but can also include the agricultural sector when it is organized as monocultural, intensive farming, and is based on the overexploitation of soils and ecosystems. This form of farming leads to an increase in the use of pesticides, herbicides and fertilizer and tends to benefit transnational and national elites. It causes local environmental damage, severe health impacts for the local population due to spraying of increasing amounts of pesticides, and the displacement and dispossession of local communities (Svampa 2012, p. 15). This type of agriculture is purely oriented towards global markets and competitiveness, not towards food sovereignty. Eduardo Gudynas (2015) uses the term "agricultural extractivism" to describe the trend towards monoculture with little or no processing, the use of transgenic crops, heavy machinery, chemical herbicides and the export of the product as a commodity.

Miguel Teubal and Norma Giarracca (2013a, p. 15) also view extractivism as connected to re-primarization and argue that there are many parallels between opencast mining and agribusiness. They define the reprimarization of the economy as the strengthening of primary products for export, which are treated as commodities, including those produced by the agribusiness and agro-industry sector for the internal market. These sectors can be highly capital intensive, generate huge profits, but employ few people and retain the characteristics of an economic enclave. They are based on the over-exploitation and exhaustion of natural resources such as water and soil, and imply environmental degradation and the depletion of human and animal health. Whereas for tens of thousands of years, agriculture did not exhaust its conditions of existence, today's practices are different. State-of-the-art technologies are promoted, such as biotechnology, information technology and nanotechnology, but normally depend on heavy and increasing pesticide use. These activities consume high quantities of non-reproducible resources such as fertile soil and biodiversity (Teubal and Giarracca 2013b, p. 23). They displace rural workers and peasants, and cause conflict with other land uses. They are not essential for local communities and do not fulfil basic needs as the commodities they produce are for export and global markets. 
Soil (exhaustion) is a major issue. The UN declared 2015 the year of soils to draw attention to the necessity of protecting soils, which the UN Food and Agricultural Organisation FAO classifies as a non-renewable resource. ${ }^{3}$ What at first seems contradictory, as soil has recovered by itself over centuries, is the outcome of an intensified form of agriculture that is continuously extracting nutrients from the soil. To counterbalance extraction, synthetic fertilizers are used more and more-about half of all synthetic fertilizers used in the history of mankind have been used in the last 25 years (UNEP 2014, p. 14). Virginia Toledo López argues that there are two different notions of agrarian extractivism (2017, p. 2), one articulated by Pengue and another by Gras and Hernandez: "mining agriculture" (Pengue 2005a, p. 19) depends on fossil inputs as it extracts too many nutrients from the soil, with soybean being one of the worst crops in this respect. This form of agriculture reinforces classical extractivism, and even with the required inputs, the quality of soils continues to worsen. In contrast, Gras and Hernandez (2013) insist that the agribusiness model itself, regardless of the type of crop or circumstances, is a form of production, commodification and organization that intensifies the extractivist features already present in agriculture.

Based on his analysis of Bolivia’s agriculture, Ben McKay (2017) proposes defining agrarian extractivism as a combination of four interlinked dimensions: firstly, large volumes of materials are extracted and destined for export with little or no processing, which fuels industrialization in the Global North. Second, the value chain is highly concentrated and controlled by a small number of enterprises, combined with sectoral disarticulation, which refers to its lack of linkages to other sectors of the economy (McKay 2017, p. 204). As a third element, McKay identifies a high intensity of environmental degradation including over-exploitation of soils, contamination of water sources, a loss of biodiversity and deforestation. Lastly, agrarian extractivism involves the deterioration of labour opportunities and/or labour conditions, as people are dispossessed of their lands and lack job opportunities. In the context of soybean, McKay

\footnotetext{
3"The large difference between erosion rates under conventional agriculture and soil formation rates implies that we are essentially mining the soil and that we should consider the resource as non-renewable. [...] However, long-term sustainability requires that soil erosion rates on agricultural land are reduced to near-zero levels" (FAO 2015, p. 103).
} 
stresses that monocultural cropping in an industrial form only offers very few jobs (ibid., p. 208).

However, McKay only sees displacement in terms of job opportunities, not in terms of land rights or violent conflict. Nevertheless, these factors also deserve to be treated as a dimension on their own. At the same time, McKay also concentrates on exports. However, other authors have argued (at least in the Argentinian context) that the production of agrofuels can also be interpreted as a form of extractivism, because it involves an accumulation mechanism based on the appropriation and exploitation of natural resources that intensifies the expansion of soybean (Toledo López 2013, p. 157). Furthermore, agrofuels_-even if they are produced for local and national use-strengthen the agribusiness model and the power of large enterprises while weakening peasant agriculture and food sovereignty (Teubal and Giarracca 2013b, p. 28).

In summary, I propose the following understanding of agrarian extractivism: agrarian extractivism is an accumulation strategy based on a model of land use that is established by agribusiness actors to profit from the monoculture of certain crops that are treated as commodities. Agrarian extractivism is based on the expulsion of peasants and indigenous groups by force and/or by market mechanisms from their traditional lands. The crops are planted to achieve the highest possible profits by selling them on a global food, fodder, fuel or energy market. Often, the crops are produced for export, but even if they are not they do not serve as food for local communities. Agrarian extractivism is based on the over-exploitation of soils and the permanent extraction of nutrients, which agribusiness seeks to compensate for by increasing the use of fertilizers, which are normally based on fossil fuels. Agrarian extractivism often goes hand in hand with strengthening large business actors, reinforced sectorial disarticulation, re-primarization and the emergence of structures typical of enclave economies. It is oriented towards the use of modern and digital technologies and machinery and contributes to an agriculture without peasants. Finally, its externalities are the destruction of soils, the contamination of water sources, a loss of biodiversity, deforestation and land concentration. 


\subsection{The Expansion of Soybean as Agrarian Extractivism in Argentina}

In the last few decades, the expansion of soybean has led the agricultural sector in Argentina to undergo tremendous change. This dynamic holds all of the characteristics of agricultural extractivism: today, soybean is the most important single crop in the country; it has transformed landscapes, social structures and even the entire economy (Lapegna 2016). In 2010, 18.5 million hectares (ha) were used for soybean production, which represented $58 \%$ of all cultivated lands in the country (Ainsuain and Echaguibel 2012, p. 93). Only one million ha (which produced 3 million metric tons of soybean) were dedicated to feeding animals in Argentina-94\% of the crop was directly exported. In 1996, Argentina became one of the first countries to permit the cultivation of GMO soybean and corn (Mikkelsen 2008, p. 171). This is referred to as "the technological package" in Argentina and it also led to the dominance of one of the biggest agricultural companies in the world, Monsanto, which holds patents on the genetically modified soybeans seeds that are resistant to the glyphosate-based pesticide Roundup. Additionally, soybean monoculture is based on a specific form of farming (no till) and a form of organizing work, which is non-intensive, but highly specialized. Furthermore, it contributes to the restructuring of the agricultural sector concerning the importance of agribusiness actors, the diminution of crop rotation, pasture farming and crop diversity (Gras and Hernandez 2013, p. 29). Moreover, transnational corporations have gained control over the sector: in 2002 only 6 companies processed $92 \%$ of soy flour, and seven TNCs controlled about $60 \%$ of exports (Lapegna 2016, p. 32). The value chain is highly concentrated, controlled by very few enterprises, and characterized by sectoral disarticulation, as soybean production lacks linkages with other sectors of the economy.

The socio-environmental impacts are huge: whereas in the 1990s, soybean monoculture was displacing cattle ranging in the Pampa, it has since expanded into more fragile ecosystems in the North-East of the country, including the temperate rain forests of the Yungas and El Chaco where it contributes to deforestation (Pengue 2005b, p. 315; Fehlenberg et al. 2017). With the expansion of GMOs and especially soybean, 
the quantity of pesticides used skyrocketed. In 1996, 39 million litres equivalent in kilos of glyphosate were used in Argentina; by 2015, this level had increased to 369 million litres. Argentina has the highest level of exposure to glyphosate per person and per year in the world (AvilaVazquez and Difilippo 2016, p. 23). This impacts heavily on human health. However, it is not only pesticide use, but also the use of fertilizer that has increased. Before 1990, most soils in the Pampa had yet to be fertilized. This changed dramatically with the cultivation of soybean, ${ }^{4}$ which played an emblematic role in the loss of Argentinian soil quality (Pengue 2005b, p. 315). Soybean is one of the crops that extracts the most from soil per unit production (Pengue 2015, p. 13). The focus in Argentina on soybean contributes significantly to the loss of soil quality. The country, therefore, exports its nutrients, and even its soil. This causes ecological debt, which risks the basis of future agriculture in Argentina (ibid., p. 14). Argentina has one of the highest rates of extraction per person in terms of material flows in Latin America (16,46 t/per capita).

The implementation of the "technological package" contributed to the possibility of cultivating soybean on soils where this had seemed impossible for a long time, and to the fact that the crop expanded towards North-East Argentina, where it displaces indigenous communities and causes conflicts over land (Toledo López 2016, p. 197; REDAF-Red Agroforestal Chaco Argentina 2013). Even those who promote soybean admit that it currently only generates 197,000 jobs, which is around $10 \%$ of the jobs in all agri-food value chains, while occupying a full $58 \%$ of agricultural land (Bragachini 2011). Although optimists expect that each direct job in this industry will generate 3.8 additional jobs in other sectors (Llach et al. 2004), they fail to account for the lost jobs due to the change in land use.

\footnotetext{
${ }^{4}$ In terms of material flows, this indicates a large change: in the 1990s, the country began exporting a considerable amount of nutrients each year-among them nitrogen and phosphorus. The country exports around 3,500,000 metric tons of nutrients a year as intensification does not allow for a process of natural replenishment to occur and means a huge loss in the long term (Pengue 2005b, p. 320).
} 


\subsection{Argentina's Expectations for the Bioeconomy}

These theoretical considerations on agrarian extractivism and this short outline of current tendencies within Argentinian agriculture form the background against which to assess the shape of the Argentinian bioeconomy. I place special emphasis on whether and how bioeconomy advocates position themselves towards GMO crops and soybean expansion. Furthermore, I examine the expectations placed on the bioeconomy to achieve a more socio-environmentally friendly form of agriculture.

Most documents on bioeconomy in Argentina start by stating that the concept was developed in Europe and in industrialized countries in particular (Guy et al. 2014). Bioeconomy has been discussed in Argentina since about 2013 and first used the framing present in many papers by the OECD and the European Union. As such, the bioeconomy was viewed as an answer to the challenges of population growth, climate change and the importance of overcoming the reliance on fossil fuels (MINCyT-Ministerio de Ciencia, Technología e Innovación Productiva n.d.). Over the years, Argentina has begun appropriating and developing its own interpretation of the concept, which can be defined as 1) a strong reliance on biotechnology and no-till farming, including the use of large amounts of fertilizers and pesticides; 2) the intention to gain "added value" and 3) a reliance on a certain number of sustainable innovations.

\subsubsection{Biotechnology, Fertilizers, Pesticides and no-till Farming as a Key Basis of Bioeconomy}

Bioeconomy is seen as a great opportunity for Argentina due to good pre-conditions in terms of resources and agricultural, industrial and economic structures (MINAGRO_Ministerio de Agroindustria 2016). The advocates of bioeconomy in Argentina are not focused on a particular crop, such as soybean, but on the opportunity to produce biomass as the key resource for economic progress. Part of the argument includes the 
claims that Argentina is a pioneer in GMO crops, and that there is broad acceptance for biotechnology within society (ibid.). Argentina has (per capita) the highest number of biotechnology companies and researchers in Latin America (ProsperA. Investment Opportunities 2009). This narrative is based on the assumption that the environmental impact of agriculture is per se diminished by biotechnology, as the following quote from the Inter-American Institute for Cooperation on Agriculture (IICA) shows:

Argentina plays a very important leading role in biotechnology for genetically modified crops. By developing our own technology, we have increased our sector's productivity and reduced the environmental impact of our production activities. (IICA 2018)

The Secretary of Food and Bioeconomy chose these words to explain that Argentina should serve as a role model to develop the bioeconomy in Latin America precisely because of the country's early and complete introduction of GMOs and its efforts to support its own biotechnology laboratories. Biotechnology laboratories have significantly expanded over the last few years and have gained new buildings and more personnel than ever before. The promoters of bioeconomy, therefore, rely on a key pillar of agrarian extractivism: GMO crops, and soybean in particular. The same actors that promote GMOs and biotechnology are now promoting the bioeconomy. Therefore, it is no surprise that there is an underlying consensus within the bioeconomy debate in Argentina that agriculture heavily relies on biotechnology and pesticides. Both are seen as necessary to produce more crops for export and internal use, and to deepen intensive agriculture. There is no questioning of monoculture production and there is no criticism within the entire bioeconomy debate about the increasing pesticide and herbicide use. Despite several campaigns by social movements (Arancibia 2013; Carrizo and Berger 2014) and alarming studies (Avila-Vazquez et al. 2018; Verzeñassi 2014), the epistemic bioeconomy community is not interested in taking up these issues.

In addition to biotechnology, new farming techniques are often presented as the solution to environmental challenges. Those arguing 
for the bioeconomy stress the need for more environmentally friendly agricultural techniques — and often present no tillage farming as the key. No-till farming was introduced with soybean expansion in Argentina. Organizations that promote no-till farming, such as AAPRESID (Argentinian Association of no-till Farming), claim to introduce a form of sustainable agriculture that protects the soil and is based on knowledge and technological innovation. Nevertheless, the scientific debate shows that the extraction of nutrients from soils and soil degradation continue with no-till farming. The soil report states:

Despite the wide adoption of no-tillage, intensive annual cultivation (largely of soybean) and the lack of rotation with other crops or pastures have resulted in soil degradation by wind and water erosion, waterlogging, compaction, sealing/capping, and soil fertility depletion. (FAO 2015, p. 368)

The issue as to whether no-till farming significantly increases soil organic stocks and how much it helps to improve the physical properties of topsoil is controversial (FAO 2015, p. 383). However, the evidence suggests that no-till farming has yet to reverse the process of soil degradation (Pengue 2015, p. 13). Moreover, as long as monocropping continues, a change of direction is unlikely. The promoters of Argentinian bioeconomy do not have any problems with monoculture, as it represents a further pillar of agrarian extractivism.

\subsubsection{Agro-Industrialization and "Adding Value" as a Key Goal Within Bioeconomy}

In the understanding of its proponents in Argentina, bioeconomy includes an opportunity to "add value" to agricultural products. This idea is also expressed by the Argentinian Stock Exchange:

The impulse of the bioeconomy is extremely attractive in countries of Latin America, in which the increase of added value to the agricultural 
primary production appears to be of crucial importance for the development of their respective economies. (Bolsa de Cereales and Wierny 2015)

Therefore, factories and installations that transform agricultural products into biofuels or biomaterials are seen as key contributors to the bioeconomy. This narrative is reproduced by a manager of an ethanol factory in the province of Córdoba (bioethanol factory manager, Interview no. 2). The strategy of "adding value" is nothing new and was dominant during the expansion of soybean monoculture (Bernhold 2019). Norma Giarracca and Miguel Teubal identify the promise of "agroindustrialization" and the "incorporation of value" as key elements put forward by proponents of agrarian extractivism (Teubal and Giarracca 2013a, p. 10). For example, in 2014 the then-Argentinian president, Cristina Fernández de Kirchner (who held office between 2007 and 2015) stressed:

We need to add value to our products. The idea is to industrialize rurality, which means that primary products have added value. Therefore, it is necessary to invest in research and development [...] fighting inequality means generating jobs and not allowing our exports to continue to be re-primarised. (Kirchner 2014)

The idea of "added value" became hegemonic under Kirchner's successor Mauricio Macri (in office between 2015 and 2019). However, neither Macri and his constituency nor the Kirchnerists are seriously concerned about the environmental impact of intensive monocultural crops.

Added value is often proposed as a counter-tendency to reprimarization and, therefore, as contributing to overcoming another pillar of agrarian extractivism. Several of my interview partners stressed that Argentina does not want to play the role of the breadbasket, or export its agricultural products, but wants to industrialize its agriculture as this is seen as a way to generate jobs in the countryside, far from the urban centres (key bioeconomy policy maker, Interview no. 1). Some argue, that doing so will even open up new jobs for highskilled labour in the countryside and provide young people with new 
opportunities (bioethanol factory manager, Interview no. 2). Many of my interview partners underline that Argentina wants a bioeconomy with social inclusion. The only form of inclusion they imagine, however, involves industrializing agricultural jobs and providing start-ups with the conditions they need to expand. Nevertheless, only a limited number of people would benefit from such policies and it is clear that most peasants, indigenous groups and landless rural workers will not do so. My interview partners argued that new entrepreneurs implement the bioeconomy on the ground. Some individuals from business support small social projects f.e. projects of urban agriculture-but this merely involves small-scale corporate social responsibility and does not involve making changes to the way in which their businesses work. Key policy makers-including those who promote bioeconomy as a development strategy-never mention other forms of participation or inclusion.

When presented as a development strategy, proponents often stress decentral units of production and the necessity to "add value" very close to the site of production:

The fact that biomass does not travel well represents an advantage for the issues connected to bioeconomy. It means that we have to opt for, or at least focus on, local development. We need to transform our surroundings as much as possible, and build the highest number of industrial plants that we can for energetic use and biomolecular enterprises etc. This leads to a focus on local systems and probably on decentralization. (key bioeconomy advisor, Interview no. 3)

The quoted advisor and others continuously stress that "biomass does not travel well", which means that it is not profitable to transport biomass over long distances. This could potentially lead to a change in agroindustrial patterns: soybean is currently transported to the next port for export, or to mills and refineries on the way to the port. In order to counteract this tendency and to improve profitability, a lot of new infrastructure needs to be built, and processing will have to be implemented on a large scale. This will have to happen if the argument that the bioeconomy represents a counter-tendency to export orientation is 
ever to be taken seriously. It is even more difficult to build a counterweight to re-primarization; industrialization grounded on bio-based products, therefore, will probably both strengthen the agricultural and the industrial sector at the same time so that the relative weight of exports from mining and agriculture diminishes. Nevertheless, as long as no or very little processing takes place, which, according to $\mathrm{CEPAL}^{5}$ categorization, includes vegetable oils and agrofuels (Gudynas 2015, p. 16), and the products continue to be sold as commodities, industrialization still contributes to re-primarization and the deepening of agrarian extractivism-even if the former president believes the opposite to be the case (Teubal and Giarracca 2013a, p. 11).

The issue of infrastructure is not seriously discussed, nor is the issue of land distribution addressed, although soybean expansion has contributed to an immense concentration of land ownership and led many farmers to give up agriculture. Additionally, in northern areas of the country, conflicts over land continue because of the expanding soybean and commodity frontiers, which are ignored by the debate entirely (REDAF 2013).

\subsubsection{On Sustainable Innovations and Counter-Tendencies to Agrarian Extractivism}

Despite the continuity in terms of actors and policy orientations between those promoting soybean and those pushing for the bioeconomy and, by implication, for a deepened agrarian extractivism, there are also some new discussions and interesting proposals that potentially contribute to more sustainable patterns of production and consumption.

First, one additional focus of the bioeconomy debate is the use of waste products as biomass. At the Córdoba symposium, a debate took place about the possibility of generating energy from meat waste. Pilot projects within the bioeconomy framework are testing how much energy can be obtained from slaughterhouse waste to produce electricity

${ }^{5}$ CEPAL is the Spanish acronym for Economic Commission for Latin America and the Caribbean. 
and heat as well as the use of bovine blood for several products with "added value" (Manfredi and Kalbermatter 2016). In the regions of Cuyo and Mendoza, many projects are working on using by-products from different agricultural production chains. ${ }^{6}$ Determining which waste products are made by different agro-industrial businesses has helped promote the re-use of by-products and to encourage cascade use. In the most recent bioeconomy symposia (1 and 2 November 2019 in Patagonia) issues were raised for the first time about food sovereignty, the contribution of indigenous knowledge about food, and female subsistence work.

Second, environmental issues are gaining importance within the Argentinian business community. For example, managers and owners of bioenergy enterprises have begun representing their enterprises as sustainable (Toledo López and Tittor 2019). They claim to be concerned about environmental issues and to seek answers within the framework provided by ecological modernization. The proponents of bioenergy and biofuel production have begun studying the $\mathrm{CO}_{2}$ emissions linked to their production processes. On the one hand, this is essential if they are to gain access to the international market. However, sometimes they discuss emission reductions that go beyond those required by international treaties (Hilbert 2016), and seriously consider issues such as the cascade use of their materials, avoiding waste and saving energy. When Bio4 realised that their production of bioethanol produced more corn by-products than farmers in the region required as feed, they constructed a bioelectricity plant next to the factory that now produces the energy needed by the enterprise (two managers from both companies, Interview no. 4 and 5). Even strong supporters of the soybean model admit that more efforts are necessary to improve environmental performance. As such, there is at least a level of recognition that a problem exists, although the solution proposed is certification of no-till farming and crop rotation. Moreover, advocates admit that although large-scale farmers organizations always recommend crop rotation, only about $30 \%$ of farmers

\footnotetext{
${ }^{6}$ See 11 presentations on the bioeconomy symposium in Cuyo between 22 and 23 September
} 2016. 
actually follow these recommendations (key bioeconomy advisor, Interview no. 3). This is because monocropping is more profitable, at least in the short-term: on average, soybean monoculture provides about $90 \%$ higher profits than a rotation system (Peretti 2013, p. 33).

Third, there are interesting and innovative small-scale projects developing as part of the bioeconomy framework; the aforementioned example of Bio4/Bioelectrica is one of them. Integrating rice cultivation and fish production, where waste from one product is used to produce the other, represents a further "success story". In this case, a pilot programme that contributes to the development of a form of rice production that forgoes the need for fertilizers and pesticides is often presented as a role model for further bioeconomy projects (bioeconomy expert, Interview no. 6).

\subsection{Conclusion: Towards an Extractive Bioeconomy?}

This chapter has shown that Argentina's bioeconomy has a clear agroindustrial and bio-technological focus. In Argentina, bioeconomy is framed as meaning further intensification of agro-industrial production-including GMOs and the immense use of pesticides - combined with strengthening industrial upgrading. The same people and institutions that have supported soybean expansion over the last few decades also advocate bioeconomy.

Environmental issues are mentioned, but GMO-seed, biotechnological processes and no-till farming are presented as key strategies with which to increase sustainability and reduce environmental impact. There are no measures to reduce pesticide use or monocultural commodity cropping. Argentina's bioeconomy is clearly a growth strategy; nature conservation and sustainability do not play central roles in this policy. Although agroecological initiatives have gained momentum within Argentina, they do not form part of the bioeconomy debate, and there is very little communication between these different epistemic communities (on one exception to this, see 
Arancibia 2013). However, the recent symposium in Patagonia indicates that this could change in the future.

Bioeconomy in Argentina does not involve a rupture with GMO crops, intensive herbicide and pesticide use or monocultures, and it continues to be strongly oriented towards global markets. Agroecological initiatives, a solidarity economy or de-centralized energy systems are not part of the debate. This form of bioeconomy has huge advantages for agricultural producers of commodity crops, biofuel producers and biotech labs. However, there is no strategy for including people such as peasants or indigenous groups in this model of development. The only form of inclusion is a vague promise of jobs due to the construction of agro-industrial installations as part of upgrading. The demands made by ecological movements in Argentina (such as to stop spraying, or to end deforestation and for environmental justice; see Merlinsky 2020) are not even recognized or addressed. Nor are the struggles against the dispossession of indigenous communities and small peasants acknowledged-processes that are often driven by agro-industrial expansion into new territories.

Argentina has not merely adopted the framing of bioeconomy by the OECD countries, but has appropriated the debate and developed its own understanding of the concept. I propose the term "extractivist bioeconomy" as characterizing this form of bioeconomy. At first glance, "extractivist bioeconomy" appears to be an oxymoron, as a bioeconomy, by definition, relies on biological processes and is aimed at sustainability. Nevertheless, there is no automatism to sustainability or to remaining inside planetary boundaries. Instead, bioeconomy in Argentina actually deepens the extractivist tendency within the dominant form of agriculture by exhausting soils due to monocropping and, therefore, deepens agrarian extractivism. As a means of overcoming soil exhaustion, pests and other problems, more biotechnology and more pesticides are said to be required. Nevertheless, these pesticides contaminate the water, ecosystems and the people who work, live and go to school near such plantations. Finally, even if the tendency towards re-primarization can be overturned through industrial upgrading and investment in infrastructure, the socio-environmental problems associated with a highly 
intensified form of agriculture based on monocropping, biotechnology and pesticides will remain.

\section{List of Interviews quoted}

\begin{tabular}{lll}
\hline Interview no. & Profession/function & Date and place \\
\hline Interview no. 1 & $\begin{array}{c}\text { Key bioeconomy policy } \\
\text { maker }\end{array}$ & 7 June 2018, Buenos Aires \\
Interview no. 2 & $\begin{array}{c}\text { Bioethanol factory } \\
\text { manager }\end{array}$ & 12 June 2018, Córdoba \\
Interview no. 3 & $\begin{array}{l}\text { Key bioeconomy advisor } \\
\text { Bioethanol factory } \\
\text { manager }\end{array}$ & $\begin{array}{l}\text { 4 June 2018, Buenos Aires } \\
\text { Interview no. 4 June 2018, Rio Cuarto }\end{array}$ \\
Interview no. 5 & $\begin{array}{c}\text { Bioelectricity factory } \\
\text { manager } \\
\text { Bioeconomy expert }\end{array}$ & 15 June 2018, Rio Cuarto \\
\hline
\end{tabular}

\section{References}

Ainsuain, O., \& Echaguibel, M. (2012). A 100 años del Grito de Alcorta. Soja, Agronegocios y explotación. Buenos Aires: Ediciones Ciccus.

Arancibia, F. (2013). Challenging the Bioeconomy: The Dynamics of Collective Action in Argentina. Technology in Society, 35, 70-92.

Avila-Vazquez, M., \& Difilippo, F.S. (2016). Agricultura tóxica y salud en pueblos fumigados de Argentina. Crítica y Resistencias. Revista de conflictos sociales latinoamericanos (2), 23-45.

Avila-Vazquez, M., Difilippo, F.S., Lean, B.M., Maturano, E., \& Etchegoyen, A. (2018). Environmental Exposure to Glyphosate and Reproductive Health Impacts in Agricultural Population of Argentina. Journal of Environmental Protection, 9, 241-253.

Bebbington, A., Cuba, N., \& Rogan, J. (2014). The Overlapping Geographies of Resource Extraction. Revista. Harvard Review of Latin America, 13(2), 20-24.

Bernhold, C. (2019). Upgrading and Uneven Development: On Corporate Strategies and Class Dynamics in Argentinian Grain and Oilseed Value Chains. Dissertation. Zurich: University Zurich. 
Bolsa de Cereales, \& Wierny, M. (2015). Medición de la bioeconomía. Cuantificación del Caso Argentino. Buenos Aires: Libro digital.

Bragachini, M. (2011). La cadena de la soja, en 10 años, puede generar 400 mil puestos de trabajo. Infocamp. https:/www.infocampo.com.ar/bragac hini-la-cadena-de-la-soja-puede-generar-400-000-puestos-de-trabajo-en-10anos/. Accessed 30 Feb 2020.

Carrizo, C., \& Berger, M.S. (2014). Luchas contra los pilares de los agronegocios en Argentina: transgénicos, agrotóxicos y CONABIA. Letras Verdes, Revista Latinoamericana de Estudios Socioambientales, 4-28.

FAO. (2015). Status of the World's Soil Resources: Main Report. Rome: FAO; ITPS.

Fehlenberg, V., Baumann, M., Gasparri, N.I., Piquer-Rodriguez, M., GavierPizarro, G., \& Kuemmerle, T. (2017). The Role of Soybean Production as an Underlying Driver of Deforestation in the South American Chaco. Global Environmental Change, 45, 24-34.

Gras, C., \& Hernandez, V.A. (2013). Los pilares del modelo agribusiness y sus estilos empresariales. In C. Gras \& V.A. Hernandez (Eds.), El agro como negocio: Producción, sociedad y territorios en la globalización (pp. 17-46, Sociedad). Buenos Aires: Biblos.

Gudynas, E. (2015). Extractivismos. Ecología, economía y política de un modo de entender el desarrollo y la Naturaleza. La Paz: Centro de Documentación e Información Bolivia (CEDIB).

Guy, H., Pahun, J., \& Trigo, E. (2014). La Bioeconomía en América Latina: oportunidades de desarrollo e implicaciones de política e investigación. Faces, 20(42), 125-141.

Hilbert, J.A. (2016, Oct 4). Impactos medioambientales de la transformación de biomasa en energía y otros productos comercializables. Estudios de casos argentinos. Bioeconomy Simposium, Córdoba.

IICA. (2018). Argentina Will Become the American Continent's Hub for Knowledge in the Field of Bioeconomy. https:/iica.int/en/press/news/arg entina-will-become-american-continent $\% 25 \mathrm{E} 2 \% 2580 \% 2599$ s-hub-knowle dge-field-bioeconomy. Accessed 30 March 2020.

Kirchner, C. (2014). Necesitamos agregar valor a nuestros productos. Celac. https://www.minutouno.com/notas/311897-cristina-kirchner-la-celac-necesi tamos-agregar-valor-nuestros-productos. Accessed 30 March 2020.

Lapegna, P. (2016). Soybeans and Power: Genetically Modified Crops, Environmental Politics, and Social Movements in Argentina. Oxford: Oxford University Press. 
Llach, J., Harriague, M., \& O’Connor, E. (2004). La generación de empleo en las cadenas agroindustriales. Buenos Aires: Fundación Producir Conservando. Manfredi, M.J., \& Kalbermatter, L. (2016, Oct 4). Valorización de subproductos de la cadena cárnica regional. Bioeconomy simposium, Córdoba, Argentina. McKay, B. (2017). Agrarian Extractivism in Bolivia. World Development, 97, 199-211.

Merlinsky, G. (2020). Cartografias del conflicto ambiental en Argentina III. Buenos Aires: Ciccus.

Mikkelsen, C.A. (2008). La expansión de la soja y su relación con la agricultura industrial. Revista Universitaria de Geografia, 17(1), 165-188.

MINAGRO. (2016). Bioeconomía Argentina. Visión desde Agroindustria. www.agroindustria.gob.ar/sitio/areas/bioeconomia/_archivos//000000_ Bioeconomia\%20Argentina.pdf. Accessed 26 May 2020.

MINCyT. (n.d.). El paradigma de la bioeconomía. http://www.bioeconomia.min cyt.gob.ar/bioeconomia-argentina/. Accessed 19 May 2020.

Pengue, W.A. (2005a). Agricultura industrial y transnacionalizacion en America Latina: ¿la transgenesis de un continente? Buenos Aires: GEPAMA-Grupo de Ecología del Paisaje y Medio Ambiente. http://aao.org.br/aao/pdfs/pub licacoes/agricultura-industrial-y-transnacionalizacion-en-america-latina.pdf. Accessed 26 May 2020.

Pengue, W.A. (2005b). Transgenic Crops in Argentina: The Ecological and Social Debt. Bulletin of Science, Technology \& Society, 25, 314-322.

Pengue, W.A. (2015). Suelos, Huellas de Nutrientes y Estabilidad Ecosistémica. Fronteras, 13, 1-18.

Peretti, P. (2013). Chacareros, soja y gobernabilidad. Del Grito de Alcorta a la Resolución 125. Buenos Aires: Ciccus.

ProsperA. Investment Opportunities. (2009). Biotechnology in Argentina. Knowledge + Innovation to Meet Global Market Needs. https://www.ass olombarda.it/fs/201029114832_122.pdf. Accessed 26 May 2020.

REDAF. (2013). Conflictos sobre tenencia de tierra y ambientales en la región del Chaco argentino. Reconquista/ Chaco: $3^{\circ}$ Informe.

Svampa, M. (2012). Bergbau und Neo-Extraktivismus in Lateinamerika. In FDCL \& RLS (Eds.), Der Neue Extraktivismus. Eine Debatte über die Grenzen des Rohstoffmodells in Lateinamerika (pp. 14-33). Berlin: FDCLVerlag.

Svampa, M., \& Viale, E. (2014). Maldesarrollo. La Argentina del Extractivismo y el despojo (2nd ed.). Buenos Aires: Katz Editores. 
Teubal, M., \& Giarracca, N. (2013a). Introducción. In N. Giarracca \& M. Teubal (Eds.), Actividades extractivas en expansión. Reprimarización de la economía argentina? (pp. 9-18). Buenos Aires: Antropofagia.

Teubal, M., \& Giarracca, N. (2013b). Las actividades extractivas en la Argentina. In N. Giarracca \& M. Teubal (Eds.), Actividades extractivas en expansión. Reprimarización de la economía argentina (pp. 19-44). Buenos Aires: Antropofagia.

Toledo López, V. (2013). Los agrocombustibles como un eje del extractivismo en la Argentina. In N. Giarracca \& M. Teubal (Eds.), Actividades extractivas en expansión. ¿Reprimarización de la economía argentina? (pp. 137-158). Buenos Aires: Antropofagia.

Toledo López, V. (2016). Agroenergía y discurso del desarrollo. Un análisis de narrativas regionales y locales a propósito de la producción de biodiesel en Santiago del Estero. In G. Merlinsky (Ed.), Cartografias del conflicto ambiental en Argentina II (pp. 197-226). Buenos Aires: Ediciones Ciccus.

Toledo López, V. (2017). La política agraria del kirchnerismo. Entre el espejismo de la coexistencia y el predominio del agronegocio. Mundo Agrario.

Toledo López, V., \& Tittor, A. (2019). Contradicciones en torno a las innovaciones y certificaciones en el sector de la bioenergía en Argentina. Letras Verdes, Revista Latinoamericana de Estudios Socioambientales, 26, 87-110.

UNEP. (2014). Assessing Global Land Use: Balancing Consumption with Sustainable Supply. https://wedocs.unep.org/bitstream/20.500.11822/8861/ 1/assessing_global_land_use.pdf. Accessed 26 May 2020.

Verzeñassi, D. (2014). Agroindustria, salud y soberanía. El modelo agrosojero y su impacto en nuestras vidas. In D. Melón (Ed.), La Patria Sojera. El modelo agrosojero en el Cono Sur (pp. 31-48). Buenos Aires: Editorial El Colectivo. 
Open Access This chapter is licensed under the terms of the Creative Commons Attribution 4.0 International License (http://creativecommons.org/ licenses/by/4.0/), which permits use, sharing, adaptation, distribution and reproduction in any medium or format, as long as you give appropriate credit to the original author(s) and the source, provide a link to the Creative Commons license and indicate if changes were made.

The images or other third party material in this chapter are included in the chapter's Creative Commons license, unless indicated otherwise in a credit line to the material. If material is not included in the chapter's Creative Commons license and your intended use is not permitted by statutory regulation or exceeds the permitted use, you will need to obtain permission directly from the copyright holder.

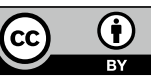

